\title{
Direct Analysis of Antarctic Krill by Slurry Sampling: Determination of Copper, Iron, Manganese and Zinc by Flame Atomic Absorption Spectrometry
}

\author{
Flávia L. Alves ${ }^{a}$, Patricia Smichowski ${ }^{b}$, Silvia Farías ${ }^{b}$, Julieta Marrero ${ }^{c}$ and Marco A. Z. Arruda ${ }^{a_{*}}$ \\ ${ }^{a}$ Departamento de Química Analítica, Universidade Estadual de Campinas-UNICAMP, \\ CP 6154, 13.083-970, Campinas - SP, Brazil \\ ${ }^{b}$ Comisión Nacional de Energía Atómica, Unidad de Actividad Química, Centro Atómico \\ Constituyentes, Av. Libertador 8250, 1429-Buenos Aires, Argentina \\ ${ }^{c}$ Comisión Nacional de Energía Atómica, Unidad de Actividad Geología, Centro Atómico \\ Ezeiza, Av. Libertador 8250, 1429-Buenos Aires, Argentina
}

\begin{abstract}
A técnica de amostragem de suspensão aliada à espectrometria de absorção atômica com chama foi empregada para a determinação direta de $\mathrm{Cu}, \mathrm{Fe}, \mathrm{Mn}$ e Zn em matrizes de Krill antártico. O efeito dos parâmetros instrumentais e o preparo das suspensões foram estudados em função do sinal analítico. Para a determinação de $\mathrm{Cu}, \mathrm{Fe}$ e $\mathrm{Zn}$, as amostras foram suspensas em uma solução de $\mathrm{HNO}_{3} 2,0$ mol L-1 e para a determinação de $\mathrm{Mn}$, o krill foi suspenso em uma solução de $\mathrm{HNO}_{3} 4,0$ mol L ${ }^{-1}$. A precisão entre as replicas foi melhor que $5 \%$. A metodologia foi aplicada para a determinação direta de $\mathrm{Cu}, \mathrm{Fe}, \mathrm{Mn}$ e Zn em amostras de krill antártico, usando padrões aquosos no preparo das curvas analíticas. Os resultados obtidos estão concordantes com os encontrados na determinação por FAAS e ICP-AES, depois da digestão das amostras em um forno de microondas. Os limites de detecção foram 4,5; 1,0; 4,9 e 8,4 $\mu \mathrm{g} \mathrm{L}^{-1}$ para $\mathrm{Cu}, \mathrm{Zn}, \mathrm{Mn}$ e Fe, respectivamente.
\end{abstract}

Slurry sampling in combination with flame atomic absorption spectrometry was employed for the direct determination of four essential trace elements, namely $\mathrm{Cu}, \mathrm{Fe}, \mathrm{Mn}$ and $\mathrm{Zn}$ in Antarctic krill. The effect of instrumental operating conditions and slurry sampling preparation on the analytical signal was investigated. For the determination of $\mathrm{Cu}, \mathrm{Fe}$ and $\mathrm{Zn}$, samples were suspended in a solution containing $2 \mathrm{~mol} \mathrm{~L}^{-1} \mathrm{HNO}_{3}$. In the case of $\mathrm{Mn}, 4 \mathrm{~mol} \mathrm{~L}^{-1} \mathrm{HNO}_{3}$ was necessary for the preparation of the slurry. The precision between sample replicates was better than $5 \%$. The method was applied to the direct determination of $\mathrm{Cu}, \mathrm{Fe}, \mathrm{Mn}$ and $\mathrm{Zn}$ in Antarctic krill samples using aqueous reference solutions to prepare the calibration curves. The results obtained were in good agreement with those achieved by FAAS and ICP-AES after microwave-assisted wet digestion of the krill samples. The detection limits were 4.5, 1.0, 4.9 and $8.4 \mu \mathrm{g} \mathrm{L}-1$ for $\mathrm{Cu}, \mathrm{Zn}, \mathrm{Mn}$ and $\mathrm{Fe}$, respectively.

Keywords: Antarctic krill, slurry, FAAS, ICP-AES

\section{Introduction}

Most analyses by flame and plasma atomization techniques are carried out on solutions using continuous nebulization to introduce the sample. In this context, the mineralization of solid samples which is necessary prior to the analysis, which increases both the time of analysis and the risk of sample contamination inherent in the dissolution of samples. For these reasons, there is considerable interest in the development of analytical methods which allow the direct analysis of solid samples. In recent years, numerous

e-mail: zezzi@iqm.unicamp.br methods have been developed in order to introduce solid samples into a variety of sources for subsequent elemental analysis ${ }^{1,2}$. Electrothermal atomization, laser ablation and glow discharge have been employed to quantify minor and trace elements in solid materials. However, a number of factors must be considered to obtain an analytical performance comparable to that achieved with liquid sampling. The introduction of the sample as a slurry is an alternative that has been used to analyze a diversity of elements in different matrices ${ }^{3-8}$. Comprehensive reviews on this methodology have been reported in the literature ${ }^{9,10}$. Slurry sampling is now an accepted technique and a very convenient way to analyze solid samples. 
The slurry sample technique arose in 1974, developed by Brady et al. ${ }^{11,12}$ and combines the advantages of solid and liquid sampling ${ }^{13}$. The main advantages of the slurry sampling technique, through direct solid sample atomization, include simplification in the prior sample treatment, time reduction in sample decomposition, minimization of contamination and analyte losses, reduction of costs and reagent consumption, as well as avoiding the use of hazardous chemicals.

Particle size and the lack of homogeneity in the sample can especially affect the precision and accuracy of the analysis, accomplished through the slurry technique. Particle size is a critical factor in slurry preparation and must be optimized to a particle diameter that will also contribute to good sample agitation ${ }^{14}$. The limited range of slurry concentration is a drawback that must also be considered. This technique permits the use of aqueous standards and/or methods of standard addition ${ }^{10,15}$ to be applied for quantification.

The slurry technique associated with flame atomic absorption spectrometry (FAAS) was first applied by Willis, ${ }^{16}$ who determined several metals in geological samples. Some problems can occur in the flame; the principal difficulty is related to the slurry particle transport through the nebulizer. ${ }^{16-21}$ In order to solve these problems related to the transport efficiency of the suspended particles in the slurry, some authors proposed the use of special nebulizers. ${ }^{22-25}$

Krill (Euphasia superba) is a small shrimp extremely abundant in the Southern Ocean that can vary in length from less than $1 \mathrm{~cm}$ to $c a .15 \mathrm{~cm}$, being mostly transparent, with large black eyes, a brught red shell, and often a vividly green stomach, but it becomes curled up and opaque when dead. The importance of krill sample analysis is based on the fact that this crustacean is a prime food source for seals, penguins and whales and these higher animals probably would not survive in the absence of the krill. The krill can accumulate trace elements and other chemicals ${ }^{26}$ and this shows promise for use as an indicator of ongoing contamination in the most pristine continent of the planet. Finally, krill is also consumed by humans, more specifically, in countries such as Chile, Russia, Japan, Poland, South Korea and Ukraine ${ }^{26}$.

The $\mathrm{Cu}, \mathrm{Zn}, \mathrm{Mn}$ and $\mathrm{Fe}$ determinations in krill samples are based on the importance of these elements in animal and human nutrition. Also, these elements constitute some of those that are included in the certification program for Antarctic samples. In this way, the aim of this study is to explore the development of a rapid and simple slurry method to determination of $\mathrm{Cu}, \mathrm{Fe}, \mathrm{Mn}$ and $\mathrm{Zn}$ in Antarctic krill and to compare the results obtained with those performed in digested krill samples by flame atomic absorption spectrometry and inductively coupled plasma atomic emission spectrometry (ICP-AES). The analysis was carried out on a certified reference material (MURST-ISSA2). This material was prepared in the framework of the Programma Nazionale per la Richerca in Antarctica (PNRA, Italian National Program for Antarctic Research) and was coordinated by the Istituto Superiore di Sanità (ISS, Itálian National Institute of Health).

\section{Experimental}

\section{Instrumentation}

A Perkin-Elmer model AAnalyst 300 flame atomic absorption spectrometer, equipped with a deuterium lamp background correction system (Norwalk, CT, USA) was used throughout this work for the analysis of slurries and digested krill samples. Hollow cathode lamps (Perkin-Elmer, Darmstadt, Germany) of $\mathrm{Cu}, \mathrm{Mn}, \mathrm{Fe}$ and $\mathrm{Zn}$ were used as the radiation source and the analytical measurements were based on time averaged absorbance. The principal FAAS operating conditions are summarized in Table 1.

Table 1. Optimized FAAS operating conditions for the determination of $\mathrm{Cu}, \mathrm{Fe}, \mathrm{Mn}$, and $\mathrm{Zn}$ in Antarctic krill.

\begin{tabular}{ccccc}
\hline Parameters & $\mathrm{Cu}$ & $\mathrm{Zn}$ & $\mathrm{Fe}$ & $\mathrm{Mn}$ \\
\hline Wavelength $(\mathrm{nm})$ & 324.8 & 213.9 & 248.3 & 279.5 \\
Spectral Band Pass $(\mathrm{nm})$ & 0.70 & 0.70 & 0.20 & 0.20 \\
Lamp current $(\mathrm{mA})$ & 15 & 15 & 30 & 20 \\
$\mathrm{C}_{2} \mathrm{H}_{2}$ Gas Flow $(\mathrm{L} \mathrm{min}-1)$ & 3.00 & 3.00 & 2.50 & 3.00 \\
Air Gas Flow $\left(\mathrm{L} \mathrm{min}\right.$ min $\left.^{-1}\right)$ & 10.00 & 10.00 & 10.00 & 10.00 \\
\hline
\end{tabular}

A Perkin-Elmer (Norwalk, CT, USA) ICP 400 sequential inductively coupled Ar plasma atomic emission spectrometer was used for the analysis of mineralized krill samples. Instrumental operating conditions are summarized in Table 2.

Solutions of Antarctic Krill were prepared by acid-assisted microwave (MW) digestion using a MLS-2000 (Milestone-FKV, Sorisole, Bergamo, Italy) equipped with temperature and pressure sensors, TFM (tetrafluoromethaxil) digestion bombs and with a magnetron of $2450 \mathrm{MHz}$.

A Cole-Parmer model 8890 ultrasonic bath (Vernon Hills, Illinois 60061, USA) was used for homogenization of the slurry prior to its introduction into the nebulizer system.

The material to be analyzed was observed under a Philips 515 (Netherlands) scanning electron microscope (SEM) that was operated at $30 \mathrm{kV}$ for secondary electron (SE) imaging. 
Table 2. Optimized operating conditions for the determination of trace elements in Antarctic krill by ICP-AES.

\begin{tabular}{lc}
\hline ICP system & Perkin-Elmer ICP 400 \\
Forward rf power $(\mathrm{kW})$ & 1.1 \\
Frequency of rf generator $(\mathrm{MHz})$ & 40 \\
Monochromator & Czerny-Turner mounting \\
Torch assembly & $\begin{array}{c}\text { demountable design quartz } \\
\text { tubing and ceramic } \\
\text { alumina injector }\end{array}$ \\
Spray chamber & Ryton Scott Double Pass \\
Coolant gas flow rate $\left(\mathrm{L} \mathrm{min}{ }^{-1}\right)$ & 15 \\
Auxiliary gas flow rate $(\mathrm{L} \mathrm{min}-1)$ & 2 \\
Sample flow rate $\left(\mathrm{L} \mathrm{min} \mathrm{m}^{-1}\right)$ & 0.8 \\
Wavelengths (nm) & Cu (I): 324.75; Fe (II): \\
& $238.20 ; \mathrm{Mn}(\mathrm{II}): 257.61 ;$ \\
Viewing height above load coil (mm) & 15 \\
Integration time (s) & 213.87 \\
Sample pump rate & $1.0 \mathrm{~L} \mathrm{~min}{ }^{-1}$ \\
\hline
\end{tabular}

\section{Standards andreagents}

Welding Ar from AGA (Buenos Aires, Argentina) was found to be sufficiently pure for $\mathrm{Cu}, \mathrm{Mn}, \mathrm{Fe}$ and $\mathrm{Zn} \mathrm{ICP}$ AES determination. Acetylene from Air Liquid (Campinas, SP, Brasil) was employed for FAAS measurements.

All solutions were prepared with analytical quality chemicals (Merck, Darmstadt, Germany) and distilled/deionized water was used throughout this work. The $\mathrm{HNO}_{3}$ used for sample digestion and slurry preparation was distilled in a quartz sub-boiling still (Marconi, Piracicaba, Brasil). The $\mathrm{H}_{2} \mathrm{O}_{2}$ used for sample mineralization was of Suprapure grade (Merck, Darmstadt, Germany). For FAAS measurements a $1000 \mathrm{mg} \mathrm{L}^{-1}$ of $\mathrm{Zn}$ (II) [from $\mathrm{Zn}\left(\mathrm{NO}_{3}\right)_{2}$ ] and $\mathrm{Fe}$ (III) [from $\left.\mathrm{Fe}\left(\mathrm{NO}_{3}\right)_{3}\right]$ solutions were prepared as stock solutions. $\mathrm{Cu}$ and Mn stock solutions were prepared from their metallic forms (99.99\% of purity). The standard solutions for $\mathrm{Cu}, \mathrm{Fe}$ and $\mathrm{Zn}$ were prepared daily by making serial dilutions with $2 \mathrm{~mol} \mathrm{~L}^{-1} \mathrm{HNO}_{3}$ and with $4.0 \mathrm{~mol} \mathrm{~L}^{-1}$ for Mn. For ICP-AES, the standards were prepared from Titrisol (Merck) flask.

\section{Sample preparation procedures}

Two different sample introduction approaches (slurry sampling and nebulization of solutions) were set up and compared to evaluate the possibility of using slurry sampling as a valid alternative for the determination of trace metals in Antarctic krill.

\section{Slurrypreparation of krill samples}

The slurry was prepared by weighing $250 \mathrm{mg}$ of lyophilized krill in a volumetric flask and completing the volume to $25 \mathrm{~mL}$ with $2.0 \mathrm{~mol} \mathrm{~L}-1 \mathrm{HNO}_{3}$ for $\mathrm{Cu}, \mathrm{Fe}$ and $\mathrm{Zn}$. In the case of the Mn, the slurry was prepared by weighing $200 \mathrm{mg}$ of lyophilised krill in a volumetric flask and completing the volume to $10 \mathrm{~mL}$ with $4.0 \mathrm{~mol} \mathrm{~L}^{-1} \mathrm{HNO}_{3}$. The slurries were sonicated for $15 \mathrm{~min}$ in an ultrasonic bath $(60 \mathrm{~Hz})$ and $\mathrm{Cu}, \mathrm{Fe}, \mathrm{Mn}$ and $\mathrm{Zn}$ were quantified by FAAS. A blank was carried through out the procedure described above. Aqueous-based calibration curves were used for quantification of these trace elements.

\section{Mineralization of krill samples}

Samples of krill were also treated using an assisted acid digestion method. A $500 \mathrm{mg}$ portion of sample was inserted into the microwave digestor, $6 \mathrm{~mL} \mathrm{HNO}_{3}$ (conc.) plus $1 \mathrm{~mL} \mathrm{H}_{2} \mathrm{O}_{2}(30 \% \mathrm{v} / \mathrm{v})$ were added and the solution was heated only after the initial reaction had subsisted. The microwave program for the decomposition of krill samples was optimized to be as short as possible and is detailed in Table 3. The average microwave power applied during the digestion cycles varied from 250 to $650 \mathrm{~W}$ and the time for complete sample digestion was less than $20 \mathrm{~min}$.

Table 3. Microwave oven program for krill sample digestion. Total time, $17 \mathrm{~min}$.

\begin{tabular}{ccc}
\hline Step & Power $(\mathrm{W})$ & Time $(\mathrm{min})$ \\
\hline 1 & 250 & 1 \\
2 & 0 & 1 \\
3 & 250 & 5 \\
4 & 400 & 5 \\
5 & 650 & 5 \\
\hline
\end{tabular}

After the decomposition, the volume was reduced to a minimum (in a ceramic plate for $c a .20 \mathrm{~min}$ ) and then the sample was transferred to the volumetric flasks and diluted to $50 \mathrm{~mL}$ with $0.014 \mathrm{~mol} \mathrm{~L}^{-1} \mathrm{HNO}_{3}$.

\section{FAASandICP-AESmeasurements}

FAAS: Slurried samples and solutions were measured relative to calibration standards of the individual element made up in $\mathrm{HNO}_{3}$. Absorbance time average measurements were employed to quantify the atomic signal of the four elements analyzed.

ICP-AES: Measurement conditions were optimized on signal-to-background ratio. Concentrations of $\mathrm{Cu}, \mathrm{Fe}, \mathrm{Mn}$ and $\mathrm{Zn}$ were calculated using the straight calibration graphs based on multielemental acidified standard solutions. In both cases, five vials were analyzed and each sample was measured three times. 


\section{Results and Discussion}

Initial experiments were carried out by preparing a $1 \%$ $(\mathrm{m} / \mathrm{v})$ suspension of krill for $\mathrm{Cu}, \mathrm{Zn}$ and $\mathrm{Fe}$ and $2 \%(\mathrm{~m} / \mathrm{v})$ for $\mathrm{Mn}$ in order to optimize different parameters.

Nitric acid has been used by several authors ${ }^{27-29}$ because the analytes are mobilized from the solid particles to the liquid media, which improves the precision of the $\operatorname{method}^{7}$, while nitrates do not interfere in the atomization paths for the metals involved. The concentrations selected, $2.0 \mathrm{~mol} \mathrm{~L}^{-1}$ for $\mathrm{Cu}, \mathrm{Fe}$ and $\mathrm{Zn}$ and $4.0 \mathrm{~mol} \mathrm{~L}^{-1}$ for $\mathrm{Mn}$, were used according to previous studies shown in Figure 1. The $\mathrm{HNO}_{3}$ concentration selected for $\mathrm{Cu}, \mathrm{Fe}$ and $\mathrm{Zn}$ was based principally on the results obtained for Fe that presented a significant increase when $\mathrm{HNO}_{3} 2.0 \mathrm{~mol} \mathrm{~L}^{-1}$ was employed in comparision to $0.014 \mathrm{~mol} \mathrm{~L}^{-1}$. As good results were already obtained for $\mathrm{Cu}$ and $\mathrm{Zn}$, the $2.0 \mathrm{~mol} \mathrm{~L}^{-1}$ acid concentration was fixed for slurry preparation. In the case of $\mathrm{Mn}$, no increase in sensibility was observe when $\mathrm{HNO}_{3}$ 4.0 or $6.0 \mathrm{~mol} \mathrm{~L}^{-1}$ was used; the lower concentration was selected for security and cost reasons.

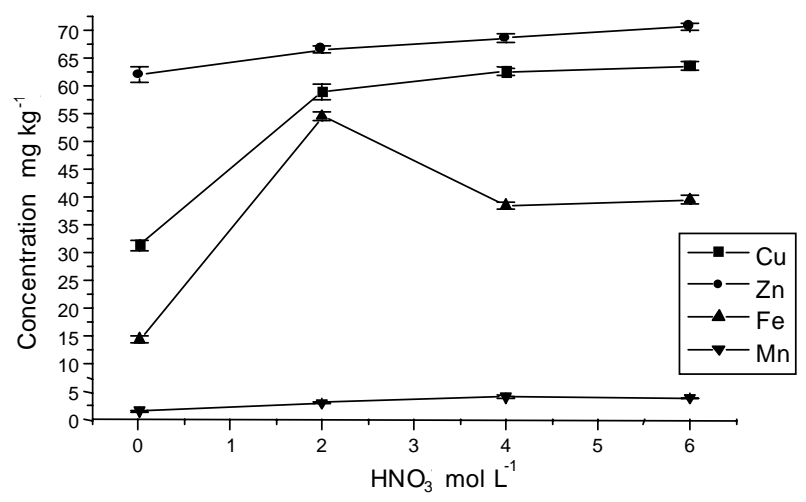

Figure 1. Studies related to nitric acid concentration for prepare the slurries samples.

\section{Stability of the slurry}

There are several critical factors in slurry preparation that must be taken into account, such as, the stability and maximum concentration of the slurry, the particle diameter and the density of the material ${ }^{30}$. The density and the diameter of particles can be the most relevant factors, because these data are used to calculate the number of particles in suspension. When particle size decreases, there will be more particles in suspension, thus sampling errors will be reduced $^{30}$. A compromise situation must be reached because if the mass of the slurry is too high, the matrix effect will affect the analytical signal. Some researchers have reported the necessity of small particle size $(<25 \mu \mathrm{m})^{30}$ for slurry analysis. The particles size of krill samples (vial $\mathrm{N}^{\circ} 1070$ ) was examinate by scanning electron microscopy (SEM), as shown in Figure 2. The material contained mostly particles of approximately $100 \mu \mathrm{m}$. Smaller particles $(20-40 \mu \mathrm{m})$ were also observed.

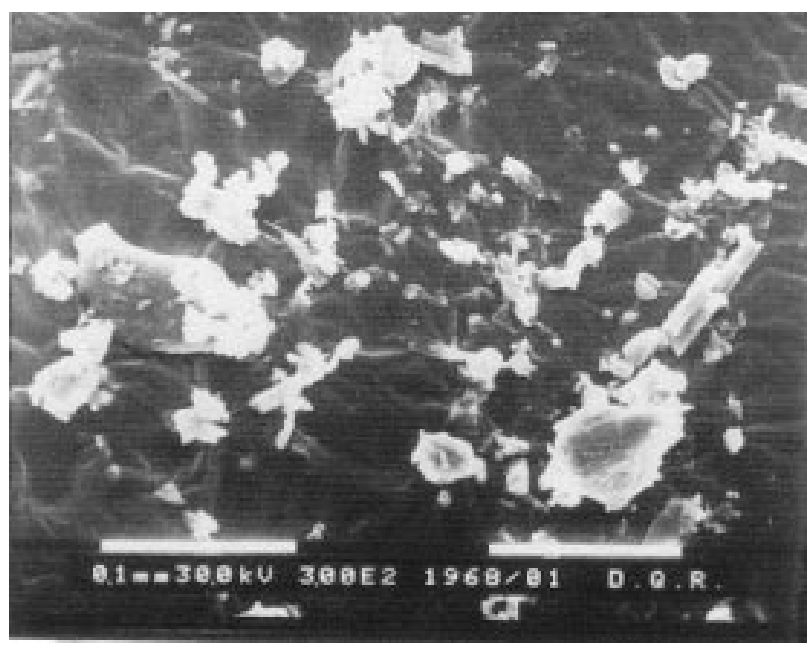

(a)

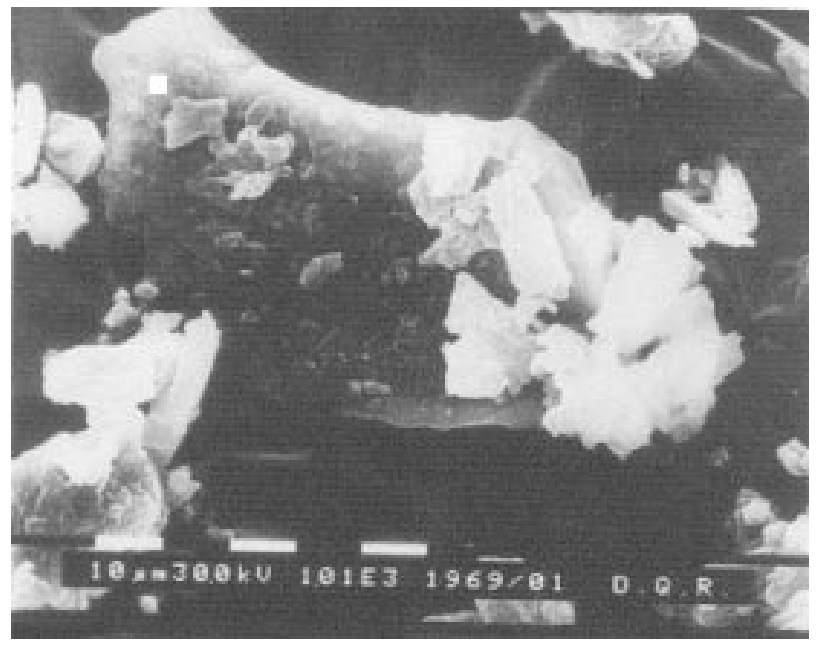

(b)

Figure 2. SEM micrographs of Antarctic krill. (a) general view and (b) zoom of the particles.

\section{Selectivityandchemical interferences}

Mineralized samples of krill were analyzed by FAAS and ICP-AES and the results were compared with those obtained by slurry sampling. Although good agreement of the results was obtained for $\mathrm{Cu}, \mathrm{Mn}, \mathrm{Fe}$ and $\mathrm{Zn}$ with both techniques.

The results obtained for the four elements examined demonstrate that the release of a specific element from the solid phase will depend on the form in which this element is present in the matrix to be analyzed. 


\section{Krill slurryanalysis}

Some difficulties were observed in the determination of trace elements in krill in suspension. After mixing the lyophilized krill with 2.0 and $4.0 \mathrm{~mol} \mathrm{~L}^{-1} \mathrm{HNO}_{3}$ and subsequent application of an ultrasonic treatment, a suspension containing gelatinous particles was observed. Conventional flame nebulization systems are prone to blocking when these slurries are introduced and ocassionaly the nebulizer was clogged during the preliminary studies. As a consequence, atomization efficiency was significantly reduced and losses in sensitivity occurred as the entire sample could not be atomized in the flame. To minimize these problems a cleaning step was made between each sample, using deionized water and a $2 \%(\mathrm{v} / \mathrm{v}) \mathrm{HNO}_{3}$ solution. Although this cleaning step increased the analysis time (ca. 10\%), it guaranteed better precision in the trace element determinations. Table 4 reports the final results for $\mathrm{Cu}, \mathrm{Fe}, \mathrm{Mn}$ and $\mathrm{Zn}$ determinations using the optimized slurry sampling method by comparing them with those obtained using FAAS and ICP-AES after microwave assisted acid digestion. In all cases the concentration values appear to agree fairly well. These results clearly demonstrate the absence of matrix effects and justify the use of aqueous standards in the calibration.

Table 4. Determination of $\mathrm{Cu}, \mathrm{Mn}, \mathrm{Fe}$ and $\mathrm{Zn}\left(\mathrm{mg} \mathrm{g}^{\mathbf{- 1}}\right)$ in Antarctic krill. Comparison of data obtained by slurry sampling-FAAS, mineralized samples-FAAS and mineralized samples-ICP-AES

\begin{tabular}{ccccc}
\hline & Slurry & $\begin{array}{c}\text { Mineralized } \\
(\text { FAAS })\end{array}$ & $\begin{array}{c}\text { Mineralized } \\
(\mathrm{ICP})\end{array}$ & Certified values \\
\hline $\mathrm{Cu}$ & $63.8 \pm 1.1$ & $64.5 \pm 1.2$ & $65.1 \pm 0.8$ & $64.1 \pm 5.1$ \\
$\mathrm{Zn}$ & $70.0 \pm 0.7$ & $68.4 \pm 0.9$ & $68.4 \pm 0.6$ & $66.0 \pm 3.1$ \\
$\mathrm{Fe}$ & $54.7 \pm 1.4$ & $58.1 \pm 1.6$ & $60.6 \pm 1.5$ & $56.6 \pm 2.8$ \\
$\mathrm{Mn}$ & $3.9 \pm 0.2$ & $4.0 \pm 0.4$ & $4.3 \pm 0.2$ & $4.1 \pm 0.2$ \\
\hline
\end{tabular}

\section{Analytical characteristics}

The detection and quantification limits were calculated following the IUPAC rules ${ }^{31}$ by ten measurements of the different blank signals. The detection and quantification limits for FAAS ranged between 1.0 and $8.4 \mu \mathrm{g} \mathrm{L}^{-1}$ and $3.5-28.0 \mu \mathrm{g} \mathrm{L}^{-1}$, respectively. For ICP-AES the detection limits ranged from $0.5-4.2 \mu \mathrm{g} \mathrm{L}^{-1}$ and the quantification limits from $1.7-13.8 \mu \mathrm{g} \mathrm{L}^{-1}$. To evaluate the accuracy of the method the results obtained were compared with the certified values as shown in Table 4. No significant differences were observed at the $95 \%$ confidence interval using the t-test. RSDs can be considered satisfactory especially if one considers the complexity of the matrix and ranged between $0.4-5.0$ for repeatability and $2.1-8.0$ for reproducibility.

\section{Conclusions}

The suspension of krill samples in nitric acid solutions is a suitable method for the determination of $\mathrm{Cu}, \mathrm{Fe}, \mathrm{Mn}$ and $\mathrm{Zn}$ at trace levels by FAAS. In particular, the comparison of the results obtained with the certified values was most encouraging. The agreement between the analyses of digested krill samples by FAAS and ICP-AES can be considered satisfactory. The precision obtained can also be considered fairly good especially if we take into account the low concentrations of the analytes and the complexity of the matrix analyzed. A simple calibration with aqueous standards is another advantage to highlight.

Although the analysis time has been increased due to the cleaning step (the total time including sample preparation + analysis of each sample is $c a .18 \mathrm{~min}$ ) the procedure is simple, reliable and not expensive, opening the possibility for use in certification programs. Further studies will be performed with this approach in the future for the analysis of other Antarctic matrices.

\section{Acknowledgements}

The authors are grateful to Sergio Caroli (Istituto Superiore di Sanità, ISS, Rome, Italy) for supplying the krill samples and Ana. G. Leyva (Comisión Nacional de Energía Atómica, Buenos Aires, Argentina) for the SEM micrographs. F. L. A and M. A. Z. A. are grateful to the Conselho Nacional de Desenvolvimento Científico e Tecnológico (CNPq, Brasília, Brazil) for fellowships and to the Fundação de Amparo à Pesquisa do Estado de S. Paulo (FAPESP, São Paulo, Brazil), grant number 98/16548-3 for financial support. We also thank Prof. C. H. Collins for language assistance.

\section{References}

1. Hirata, T.; Akagi, T.; Masuda, A. Analyst 1990, 115, 1329.

2. Caroli, S. ICP Inform. Newslett. 1994, 20, 49.

3. Ebdom, L.; Wilkinson, J. R. J. Anal. At. Spectrom. 1987, 2, 325.

4. Miller-Ihli, N. J. Fresenius'J. Anal. Chem. 1990, 337, 271.

5. Cabrera, C.; Madrid, Y.; Cámara, C. J. Anal. At. Spectrom. 1994, 9, 1423.

6. Januzzi, G. S. B.; Krug, F. J.; Arruda, M.A. Z. J. Anal. At. Spectrom. 1997, 12, 375.

7. Bermejo-Barrera, P.; Moreda-Piñeiro, A.; MoredaPiñeiro, J.; Bermejo-Barrera, A. Talanta 1998, 45, 1147.

8. Mierzwa, J.; Sun, Y. -Ch.; Yang, M. -H. Spectrochim. Acta Part B, 1998, 53, 63. 
9. Bendicho, C.; De Loos-Vollebregt, M. T. C. J. Anal. At. Spectrom. 1991, 6, 353.

10. Miller-Ihli, N. J. Anal. Chem. 1992, 64, 964 A.

11. Brady, D. V.; Montalvo, J. G.; Jung, J.; Curran, R. A. At. Absorpt. Newslett. 1974, 13, 118.

12. Brady, D. V.; Montalvo, J. G.; Glowacki, G.; Pisciotta, A. Anal. Chim. Acta 1974, 70, 448.

13. Stephen, S. C.; Littlejohn, D.; Ottaway, J. M. Analyst 1985, 110, 1147.

14. Arruda, M. A. Z.; Gallego, M.; Valcárcel, M. Quim. Anal. 1995, 14, 17.

15. Langmyr, F. J. Analyst 1979, 104, 993.

16. Willis, J. B. Anal. Chem. 1975, 47, 1752.

17. Fuller, C. W. Analyst 1976, 101, 961.

18. O'Reilly, J. E.; Hickis, D. G.Anal. Chem. 1979, 51, 1905.

19. Alder, J. F.; Backlow, P. L.At. Absorpt. Newslett. 1979, $18,123$.

20. Stupar, J.; Ajlec, R. Analyst 1982, 107, 144.
21. Petrucci, G.; Van Loon, J. C. Fresenius'Z. Anal. Chem. 1987, 326, 345.

22. Fry, R. C.; Denton, M. B. Anal. Chem. 1977, 49, 1413.

23. Suddendorf, R. F.; Boyer, K. W. Anal. Chem. 1978, 50, 1769.

24. Wolcott, J. F.; Sobel, C. B. Appl. Spectrosc. 1978, 32, 591.

25. Mohamed, M.; Fry, R. C. Anal. Chem. 1981, 53, 450.

26. Caroli, S.; Senofonte, O.; Caimi, S.; Pucci, P.; Pawels, J.; Kramer, G. N. Fresenius'J. Anal. Chem. 1998, 360, 410.

27. Miller-Ihli, N. J. Fresenius' J. Anal. Chem. 1993, $345,482$.

28. Viñas, P.; Camplillo, N.; López-García, I.; HernándezCórdoba, M. Fresenius'J. Anal. Chem. 1994, 349, 306.

29. Viñas, P.; Camplillo, N.; López-García, I.; HernándezCórdoba, M. Talanta 1995, 42, 527.

30. Miller-Ihli, N. J. J. Anal.Atom. Spectrom. 1994, 9, 1129.

31. Analytical Methods Committee Analyst 1987, 112, 199.

Received: September 17, 1999

FAPESP helped in meeting the publication costs of this article. 